\title{
Foraging Behavior and Energetics of Albatrosses in Contrasting Breeding Environments
}

\section{OPEN ACCESS}

Edited by:

Graeme Clive Hays,

Deakin University, Australia

Reviewed by:

Gail Schofield

Deakin University, Australia Yannis Peter Papastamatiou, Florida International University, United States

*Correspondence:

Michelle Antolos michelle.antolos@gmail.com

${ }^{\dagger}$ Present Address: Michelle Antolos, Department of Fisheries and Wildlife, Oregon State University, Corvallis, OR United States Scott A. Shaffer, Department of Biological Sciences, San Jose State University, San Jose, $C A$, United States Yann Tremblay

UMR MARBEC, IRD - Ifremer - Univ. Montpellier - CNRS, Sète, France

Specialty section:

This article was submitted to Marine Megafauna,

a section of the journal Frontiers in Marine Science

Received: 19 September 2017 Accepted: 01 December 2017 Published: 15 December 2017

Citation:

Antolos M, Shaffer SA, Weimerskirch $H$, Tremblay $Y$ and Costa DP (2017) Foraging Behavior and Energetics of Albatrosses in Contrasting Breeding Environments.

Front. Mar. Sci. 4:414. doi: 10.3389/fmars.2017.00414

\section{Michelle Antolos ${ }^{1 * t}$, Scott A. Shaffer ${ }^{1 \dagger}$, Henri Weimerskirch ${ }^{2}$, Yann Tremblay ${ }^{1 \dagger}$ and Daniel P. Costa ${ }^{1}$}

${ }^{1}$ Department of Ecology and Evolutionary Biology, University of California, Santa Cruz, Santa Cruz, CA, United States, ${ }^{2}$ Centre d'Études Biologiques de Chizé, Centre National de la Récherche Scientifique, Villiers en Bois, France

Animals can maximize fitness by optimizing energy acquisition through the selection of favorable foraging habitats, but trade-offs exist between time spent in preferred feeding habitats, energetic costs of travel, and reproductive constraints. For pelagic seabirds, geographic distribution of suitable breeding islands can restrict access to marine prey resources and influence foraging strategies. Laysan (Phoebastria immutabilis) and black-footed albatrosses (P. nigripes) breeding in the Northwest Hawaiian Islands, and Indian yellow-nosed albatrosses (Thalassarche carteri) breeding in the Southern Indian Ocean, utilize productive subtropical-subpolar transition zones during their breeding and non-breeding periods, but this marine feature is at a comparatively greater distance for Hawaiian albatrosses during the breeding period due to location of nesting islands. We investigated the foraging behavior and energetics of these three species to evaluate how proximity to preferred marine habitats has influenced their overall foraging strategies. During incubation, all three species traveled to subtropical-subpolar transition zones, however, Hawaiian albatrosses ranged farther to reach this habitat. All species reduced time at sea during brooding, and Hawaiian albatrosses reduced their foraging ranges to distances similar to yellow-nosed albatrosses. As a consequence, Hawaiian albatrosses foraged in the warm, oligotrophic environment of the subtropical gyre during brooding while yellow-nosed albatrosses continued to forage in a subtropical-subpolar transition zone. Landing rates, an indicator of foraging effort, did not differ between reproductive stages and were highly variable within and among species. Hawaiian albatrosses generally spent more time in flight compared to yellow-nosed albatrosses, a strategy that may relate to searching for dispersed and unpredictable prey. Mean absolute field-metabolic rate (FMR) was greatest for black-footed albatrosses, and similar between Laysan and yellow-nosed albatrosses, but mass-specific FMR did not differ between species. Hawaiian albatrosses had lower total body water than yellow-nosed albatrosses (indicating greater lipid reserves), and had FMRs that fell below the allometric relationship for studied albatross species, attributes that likely reflect physiological adaptations for foraging in a low-productivity environment.

Keywords: Laysan albatross, black-footed albatross, Indian yellow-nosed albatross, foraging behavior, activity patterns, satellite tracking, doubly labeled water, energetics 


\section{INTRODUCTION}

Animals can maximize fitness by optimizing energy acquisition through the selection of preferred habitats (Emlen, 1966; MacArthur and Pianka, 1966; Levins, 1968; Pyke, 1984), however, trade-offs exist when preferred foraging habitats are distant to breeding habitats (Charnov, 1976; Orians and Pearson, 1979; Alerstam and Högstedt, 1982; Weimerskirch and Cherel, 1998). In the marine environment, animals that breed on land but forage at sea should adopt a strategy that optimizes energy gain while minimizing the cost of transporting energy resources (e.g., food, oil, milk) back to the breeding site (Ricklefs, 1983; Pennycuick et al., 1984; Costa, 1991; Houston, 1993; Costa and Shaffer, 2012). Because marine prey are patchily distributed within a fluid, dynamic environment (MacKas and Boyd, 1979; Russell et al., 1992; Fauchald et al., 2000; Weimerskirch, 2007), marine predators can optimize energy acquisition by exploiting physical oceanographic features that aggregate prey resources (Schneider, 1990; Hunt, 1997; Hunt et al., 1998; Croll et al., 2005; Keiper et al., 2005). According to central place foraging theory, whether or not an individual selects a prey patch depends on its distance to the central place as well as its quality (Orians and Pearson, 1979; Olsson and Bolin, 2014). Therefore, proximity of the breeding site to productive marine habitat is likely to play a role in shaping foraging strategies of marine predators (Costa, 1993; Harding et al., 2013).

For pelagic seabirds, access to preferred marine habitats during the breeding season depends on location of the breeding colony, reproductive stage, and energetic costs of travel (Orians and Pearson, 1979; Weimerskirch et al., 1993; Guinet et al., 1997; Shaffer et al., 2003). Albatrosses are well-adapted to long-distance travel due to their economical mode of flight (Pennycuick, 1982; Costa and Shaffer, 2008; Sibly et al., 2012) and anatomical specialization for soaring and gliding (Pennycuick, 1982), which enable low flight costs (Costa and Prince, 1987; Shaffer et al., 2004). Albatross foraging range is variably constrained during the breeding period, however, due to changing energetic requirements at the nest. During incubation, the fasting capabilities of adults allow breeding pairs to alternate long shifts at the nest $(\sim 2-3$ weeks) with far-ranging trips to sea. Foraging range contracts toward the end of incubation, and becomes most restricted during the brooding period, when young chicks require frequent meals and adults alternate short trips to sea ( $\sim 3$ days) with time spent at the nest provisioning young chicks. The chick-rearing period begins when the fasting and thermoregulatory capabilities of chicks have developed sufficiently for them to remain at the nest independently, enabling both adults to take longer trips to sea ( $\sim 2-3$ weeks). Albatrosses are therefore able to search for prey resources in productive habitats on basin-wide scales during the incubation and chick-rearing periods (Jouventin and Weimerskirch, 1990; BirdLife International, 2004; Kappes et al., 2015), but are limited to short-distance trips during brooding, when energy deficits can occur in order to maximize food delivery to the chick (Ricklefs, 1983; Shaffer et al., 2003). When rearing larger chicks, albatrosses allocate resources between themselves and their offspring, and may employ a dual foraging strategy, whereby adults maximize prey delivery to chicks by making short-distance trips, and restore their body condition when making long-distance trips (Weimerskirch et al., 1997).

Laysan (Phoebastria immutabilis) and black-footed albatrosses ( $P$. nigripes) breeding in the Hawaiian Islands, and Indian yellow-nosed albatrosses (Thalassarche carteri) breeding on Amsterdam Island in the southern Indian Ocean, utilize similar marine habitats (in two different ocean basins) when making long-range movements, but differ in terms of accessibility of preferred foraging habitats during the breeding period. On long foraging trips during incubation and chick-rearing, all three species utilize subtropical-subpolar transition zones (Hyrenbach et al., 2002; Pinaud and Weimerskirch, 2005; Pinaud et al., 2005; Kappes et al., 2015) where warm, subtropical waters come into contact with cooler, subpolar waters (Backus, 1986; Olson, 2001). These are highly productive pelagic habitats (Lutjeharms and Valentine, 1984; Barange et al., 1998; Read et al., 2000; Olson, 2001; Polovina et al., 2001) that provide enhanced foraging opportunities for surface-feeding predators like albatrosses because surface convergence along frontal boundaries can aggregate neustonic or buoyant prey (Olson and Backus, 1985; Franks, 1992; Govoni and Grimes, 1992; Olson et al., 1994). During the brooding period, however, when albatrosses take shorter foraging trips, Laysan and black-footed albatrosses are restricted to foraging in warm, oligotrophic waters (Fernández et al., 2001; Kappes et al., 2010, 2015) where prey abundance may be lower (Ashmole, 1971; Ballance et al., 1997). Conversely, yellow-nosed albatrosses have access to cooler, more productive waters similar to habitats utilized during incubation and chick-rearing (Figure 1; Pinaud and Weimerskirch, 2005; Pinaud et al., 2005). The latter case is more characteristic of albatrosses in general; most albatrosses breed on islands in productive pelagic or coastal upwelling environments (Tickell, 2000).

We compared the foraging movements and activity patterns of Laysan, black-footed, and yellow-nosed albatrosses during the incubation and brooding periods, and measured energy expenditure during the brooding phase. By comparing closely related species with breeding locations that differ in terms of proximity to preferred marine habitats, we evaluated how these species respond behaviorally and physiologically to differing environmental conditions and reproductive demands. We hypothesized that during incubation, when all three species forage in productive subtropical-subpolar transition zones, activity patterns would be similar among species, but that differences would emerge during brooding when Hawaiian albatrosses are constrained to forage in an oligotrophic environment and competition for resources is likely high. Specifically, we hypothesized that Hawaiian albatrosses would spend more time in flight than yellownosed albatrosses during brooding, due to greater time spent in transit between more dispersed prey patches. We also hypothesized that Laysan and black-footed albatrosses would have lower landing rates and expend less energy at sea than yellow-nosed albatrosses during brooding, as a means of reducing energetic costs of foraging in a low-productivity environment. 
A

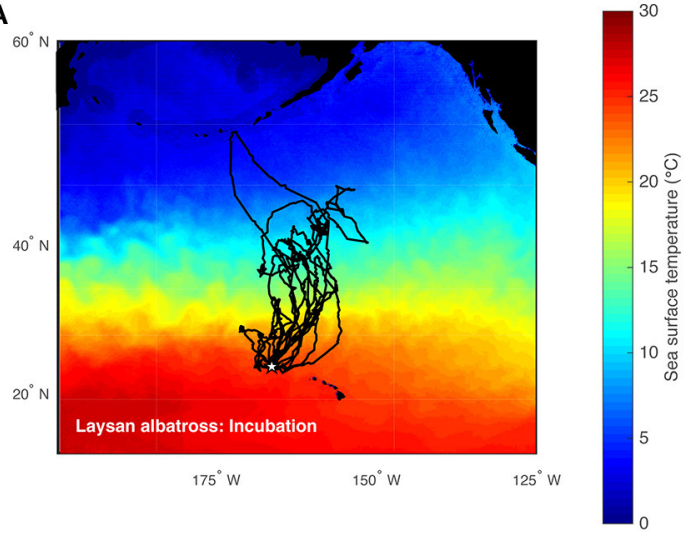

B

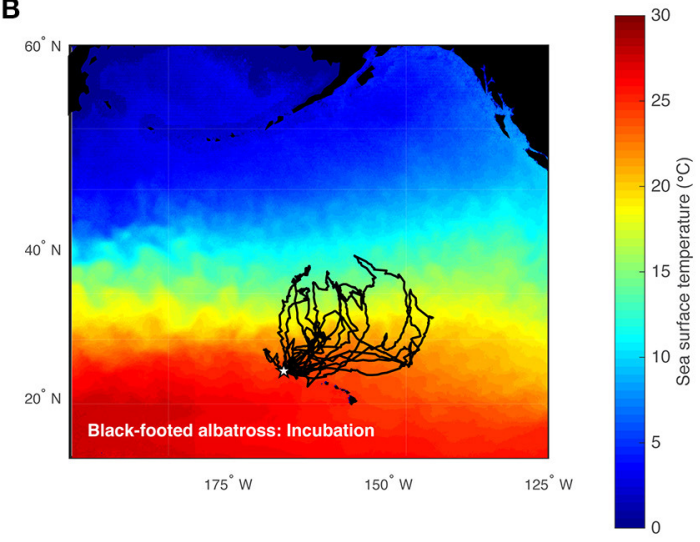

C

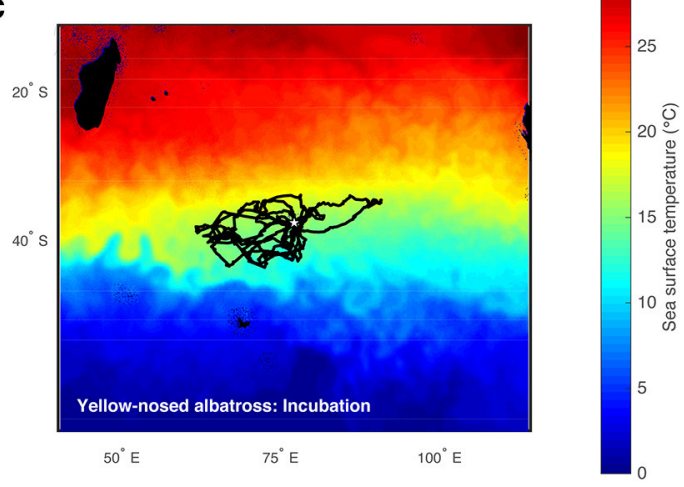

D

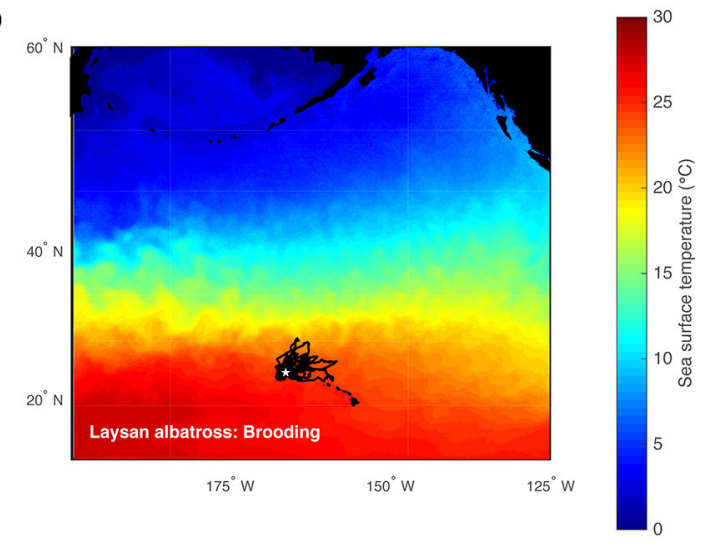

$\mathbf{E}$

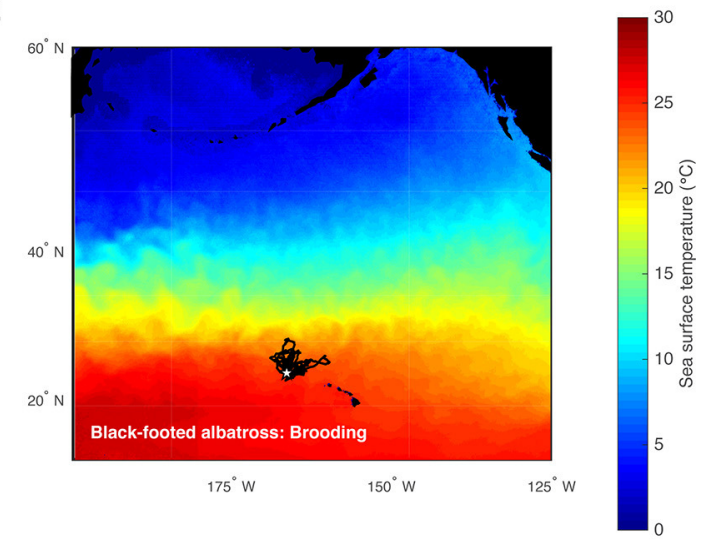

$\mathbf{F}$

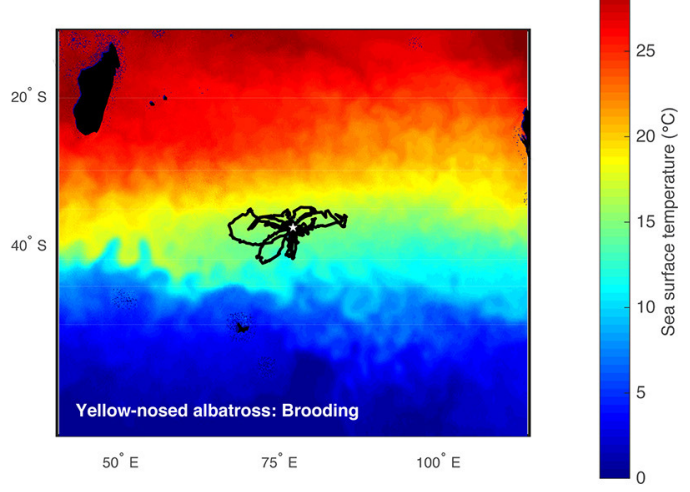

FIGURE 1 | Foraging trips of Laysan, black-footed, and Indian yellow-nosed albatrosses during late incubation (A-C) and brooding (D-F). Laysan and black-footed albatrosses were tracked at Tern Island, Northwest Hawaiian Islands during 2002-2003, 2004-2005, and 2005-2006, and yellow-nosed albatrosses were tracked at Amsterdam Island, southern Indian Ocean, during 2006-2007 (study colonies indicated with a star). Tracks are superimposed on time-averaged Blended 5-day sea surface temperature $\left({ }^{\circ} \mathrm{C}\right)$ for the respective study periods retrieved via the NOAA OceanWatch Live Access Server (http://coastwatch.pfel.noaa.gov/erddap/).

\section{METHODS}

\section{Tracking Activities}

We studied Laysan and black-footed albatrosses at Tern Island $\left(23.87^{\circ} \mathrm{N}, 166.28^{\circ} \mathrm{W}\right)$, French Frigate Shoals, Northwest Hawaiian Islands during the 2002-2003, 2004-2005, and
2005-2006 breeding seasons, and Indian yellow-nosed albatrosses at Amsterdam Island $\left(37.86^{\circ} \mathrm{S}, 77.52^{\circ} \mathrm{E}\right)$, Southern Indian Ocean, during the 2006-07 breeding season. We used satellite telemetry to determine at-sea locations of foraging albatrosses during late incubation and brooding to characterize differences in behavior between species and reproductive stages. 
During brooding, we also measured field metabolic rates of tracked albatrosses using the doubly labeled water technique (Lifson and McClintock, 1966; Nagy, 1980; Speakman, 1997).

Seventy-five adult albatrosses were equipped with satellite platform terminal transmitters (30 g Pico-100, Microwave Telemetry, Columbia, MD; and 35 g SPOT4, Wildlife Computers, Redmond, WA) during late incubation (within 2 weeks of hatch date; 10 Laysan, 11 black-footed, 11 yellow-nosed albatrosses) and brooding (15 Laysan, 13 black-footed, 15 yellow-nosed albatrosses). Satellite tags were attached to dorsal feathers with adhesive tape (tesa ${ }^{\circledR}$, Hamburg, Germany), and satellite transmissions were downloaded via the Argos satellite system (Service Argos, Inc., Largo, MD). Individuals were also equipped with temperature recorders (10g Lotek LTD 2400 and 1100, Lotek Wireless, St. John's, Newfoundland) attached to a plastic leg band so that temperature recordings $\left( \pm 0.05^{\circ} \mathrm{C}\right)$ could be used to characterize activity patterns while at sea (Wilson et al., 1995). Foraging activity is only presented for the brooding period, when high-resolution (12s) temperature records were available. In all cases, total mass of deployed devices was $<2 \%$ of bird body mass, which is under the recommended limit for albatross tracking studies (Phillips et al., 2003). Sex was determined from blood samples (Fridolfsson and Ellegren, 1999) for all individuals tracked. All protocols employed in this study were approved by the Institutional Animal Care and Use Committees, University of California Santa Cruz.

\section{Foraging Behavior}

We delimited albatross foraging tracks based on visual observations of departure and arrival times from twice-daily nest checks during incubation, and hourly nest checks from dawn to dusk during brooding. To remove unlikely Argos locations, tracks were filtered using the Iknos Toolkit (Y. Tremblay, unpublished program) for Matlab (The MathWorks, Natick, MA), following Kappes et al. (2010). First, a speed filter of $80 \mathrm{~km}$ $\mathrm{h}^{-1}$ was applied to transit rates between successive locations (following Hyrenbach et al., 2002; Suryan et al., 2006) to remove unrealistic flight speeds (Spear and Ainley, 1997). Next, the maximum change in azimuth was set to $170^{\circ}$ to remove track spikes between successive locations that are likely to be erroneous (Keating, 1994; Freitas et al., 2008). Finally, to avoid errors in transit rate determination (Hays et al., 2001), the minimum time between successive fixes was set to $10 \mathrm{~min}$.

We calculated maximum distance traveled from the colony using great-circle distances to account for the earth's curvature. We divided great-circle distances between off-colony Argos locations by the time between successive locations to calculate average transit rate. To characterize albatross foraging activity patterns, we determined the proportion of time spent in flight and the frequency of landings on the sea surface. Landing rates are indicative of feeding effort (Weimerskirch et al., 2000; Shaffer et al., 2001a) because albatrosses must land on the sea surface in order to consume prey (Conners et al., 2015). Previous research has demonstrated that take-offs and landings are the most energetically demanding activities albatrosses engage in at sea (Weimerskirch et al., 2000), and landing rates of wandering albatrosses (Diomedea exulans) are correlated with field metabolic rates (Shaffer et al., 2001a). We used an algorithm (Iknos toolkit for Matlab; Y. Tremblay, unpublished program; Kappes et al., 2015) to identify landings based on rapid changes in temperature, and stable periods associated with sitting on the sea surface (Wilson et al., 1995), for those individuals equipped with temperature records. We defined daylight hours based on civil twilight (sun no more than $6^{\circ}$ below the horizon) using NOAA's solar calculator in the maptools package in $\mathrm{R}$ (Lewin-Koh and Bivand, 2010) and temporally-matching to tracking locations.

\section{Field Metabolic Rates}

Doubly labeled water was used to determine field metabolic rates (FMR) of Laysan, black-footed, and yellow-nosed albatrosses at sea $\left(F M R_{a t-s e a}\right)$ and at the nest $\left(F M R_{\text {on-nest }}\right)$ during the brooding period (Lifson and McClintock, 1966; Nagy, 1980; Speakman, 1997). Fifteen birds of each species were captured at the nest immediately following a mate switch, and an initial blood sample (0.5-3.5 ml) was collected from a vein on the tarsus. Albatrosses were given an intraperitoneal injection of $1.6-1.9 \mathrm{ml}$ sterile water containing $0.9 \% \mathrm{NaCl}$, and either 34.5 atom percentage oxygen18 and 35.9 atom percentage deuterium (Laysan and black-footed albatrosses), or 29.8 atom percentage oxygen-18 and $5.0 \mathrm{Mbq} \mathrm{g}^{-1}$ of tritiated water (yellow-nosed albatrosses). Mass of injectate $( \pm 0.01 \mathrm{~g})$ was determined by weighing the syringe before and after injection using a portable field balance (Ohaus Corp., Pine Brook, NJ). Each bird was weighed to the nearest $50 \mathrm{~g}$ using either a spring-loaded Pesola (Pesola AG, Baar, Switzerland) or Salter scale (Salter Weightronix Ltd, West Bromwich, UK) and then placed in a box or holding pen; isotopes were allowed to equilibrate for $\sim 90 \mathrm{~min}$ (Shaffer et al., 2001b) before a second blood sample was collected. Three Laysan, two black-footed, and three yellow-nosed albatrosses were held for $3 \mathrm{~h}$ to help ensure equilibration when there was evidence that injections may have been made into the gastrointestinal cavity or cutaneous fat. All individuals were equipped with satellite tags and/or temperature recorders and released at the nest. After completion of a foraging trip, each bird was recaptured and a third blood sample was collected, within $2-3 \mathrm{~h}$ of returning to the colony. Satellite tags and temperature recorders were then removed and final body mass was measured. To determine $F M R_{\text {on-nest }}$, three Laysan, four black-footed, and three yellow-nosed albatrosses were subsequently captured after 2 days at the nest and a fourth blood sample was collected from these individuals. In one instance, a Laysan albatross did not depart to sea after release, but instead switched with its mate again and remained on the nest; for this individual only $F M R_{\text {on-nest }}$ was calculated. This doubleswitching behavior was also observed at Laysan and black-footed albatross nests checked daily to determine attendance patterns of control individuals.

Due to equipment limitations, one black-footed albatross was equipped with a temperature recorder only, two yellow-nosed albatrosses were equipped with satellite tags only, and one blackfooted albatross was equipped with a GPS tag (TechnoSmart, Rome, Italy) rather than a satellite tag; in this case, the GPS record demonstrated that the individual stayed near Tern Island overnight and then returned to the nest (short departures were also observed in control pairs, with both members of the pair 
remaining at the nest for several days in some cases). As this was not representative of $F M R_{a t-s e a}$ or FMR $R_{\text {on-nest }}$, the metabolic rate measured for this individual is not included in the subsequent analyses.

All blood samples were collected with a syringe and 21-25 gauge needle, transferred to a vacutainer (B-D brand with spraycoated lithium heparin, Beckton-Dickinson, Franklin Lakes, NJ) and stored in a cooler with cold packs until centrifugation on the day of collection. Plasma was transferred to $2 \mathrm{ml}$ cryogenic plastic screw cap vials (with silicon O-rings; Corning Inc., Corning, NY) and frozen until isotopic analyses were performed. Aliquots of water distilled from plasma samples (following Ortiz et al., 1978) were then used to determine specific activity of deuterium by laser-absorption spectroscopy (University of California Davis, Davis, CA) or tritium by scintillation spectrometry (LS 6500, Beckman Coulter Inc., Fullterton, CA) in triplicate; specific activity of oxygen-18 was determined by mass ratio spectrometry (Metabolic Solutions, Nashua, NH).

The initial dilution space of oxygen-18 was used to calculate the volume of initial total body water. To calculate final body water volume, body mass at recapture was multiplied by the initial fractional water content, which has been validated in Shaffer et al. (2006). $\mathrm{CO}_{2}$ production was calculated using equation 2 in Nagy (1980); this equation assumes that body mass of the animal changes linearly with time. For two yellow-nosed albatrosses and one Laysan albatross, FMR was determined using the single sample method described in Speakman (1997), because initial total body water calculations suggested isotopes were not fully equilibrated when the post-equilibration blood sample was collected. FMR ( $\mathrm{mL} \mathrm{g}^{-1} \mathrm{~h}^{-1}$ ) was converted to $\mathrm{kJ}$ (and $\mathrm{W}$ ) by applying a conversion factor of $24.7 \mathrm{~kJ}=1 \mathrm{~L} \mathrm{CO}$ following (Pettit et al., 1988), based on chemical composition of the diet of Laysan albatrosses (Harrison et al., 1983); this conversion factor was assumed to approximate $\mathrm{CO}_{2}$ yield from the diet of black-footed and yellow-nosed albatrosses. Mass-specific FMR ( $\mathrm{W} \mathrm{kg}^{-1}$ ) was determined by dividing FMR by mean body mass so that energy expenditure is more directly comparable among species. Because FMR calculations included time spent at the nest before departure and after arrival at the nest, measured FMR was corrected based on visual observations of departure and arrival times at the nest. Following methods of Costa and Prince (1987), $F M R_{a t-s e a}$ was calculated as:

$$
\begin{aligned}
& F M R_{\text {at }- \text { sea }}= \\
& \frac{\left[\text { measured } F M R-\left(F M R_{\text {on-nest }} \times \text { proportion of time ashore }\right)\right]}{\text { proportion of time at sea }}
\end{aligned}
$$

We compiled average FMR and body mass values for Hawaiian and yellow-nosed albatrosses with values from other studies (male and female wandering albatrosses (Shaffer et al., 2001a), shy albatrosses (Thalassarche cauta; Green and Brothers, 1995, Abstract from First International Albatross and Petrel Conference, Hobart, Australia), gray-headed albatrosses (T. chrysostoma; Costa and Prince, 1987), black-browed albatrosses (Thalassarche melanophrys; Shaffer et al., 2004), and Laysan albatrosses during incubation (Pettit et al., 1988) to provide a mechanism for comparing energy expenditure among species (Shaffer, 2011). Given large differences in mass between wandering albatrosses and other studied albatross species, we tested for the effect of genus Diomedea in the relationship between log-transformed FMR and body mass values.

\section{Statistical Analysis}

Statistical analyses were implemented in the program R ( R Development Core Team, 2010). We used ANOVA and Tukey multiple comparison tests (Hothorn et al., 2008) to investigate differences in foraging behavior between species and reproductive stages, and species differences in FMR, total body water, body mass, and foraging activity; Bonferronicorrected $P$-values are presented for multiple comparisons. Trip characteristics, landing rates, time in flight, total body water, and FMR for each species did not differ significantly between the sexes, therefore males and females were grouped for all analyses. To meet normality assumptions, percent time in flight was arcsine transformed and landing rate was log transformed prior to analysis. Simple linear regression was used to investigate relationships between foraging behavior and $F M R_{a t-s e a}$ for each species, and to examine the allometric relationship between log-transformed FMR and body mass for albatrosses from this and other studies. $P$-values reported are two-tailed, and the significance level was set as $\mathrm{P}=0.05$. All averages are reported as Mean $\pm S D$.

\section{RESULTS}

\section{Foraging Behavior}

Hawaiian albatrosses traveled significantly farther during incubation compared to brooding (more than four times as far on average; Table 1; $P<0.001$ for pair-wise tests), whereas maximum foraging range did not differ between incubation and brooding for yellow-nosed albatrosses $(P=$ 0.08). All three albatross species took foraging trips of longer duration during incubation compared to brooding $(P<0.01$ for all pair-wise tests): Hawaiian albatrosses took trips that were more than three times longer, whereas yellow-nosed albatrosses took trips that were just under two times longer on average (Table 1). During the incubation period, the majority of Hawaiian albatrosses traveled north of the Tern Island colony to cooler waters of the North Pacific Transition Zone; during brooding, their movements were restricted to warmer waters of the subtropical gyre (Figures 1, 2). Yellow-nosed albatrosses foraged in similar thermal environments during the incubation and brooding periods (Figure 2). Black-footed albatrosses traveled more rapidly during incubation compared to brooding $(P=0.02)$; transit rates did not differ between breeding stages for Laysan and yellow-nosed albatrosses (Table 1).

During the incubation period, Hawaiian albatrosses traveled farther (over $700 \mathrm{~km}$ on average) and more rapidly $\left(9 \mathrm{~km} \mathrm{~h}^{-1}\right.$ on average) than yellow-nosed albatrosses $(P<0.02$ for pair-wise tests), but spent a similar amount of time at sea (between 7 and 10 days on average). During brooding, all three species traveled similar distances $(\sim 400 \mathrm{~km})$ and durations (3-4 days). Laysan albatrosses traveled more rapidly than yellow-nosed albatrosses 


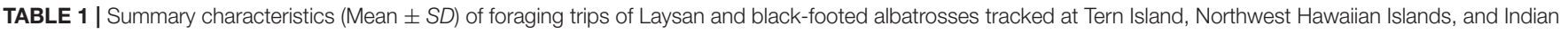
yellow-nosed albatrosses tracked at Amsterdam Island, southern Indian Ocean, during late incubation and brooding.

\begin{tabular}{|c|c|c|c|c|}
\hline Breeding period & & Laysan albatross & Black-footed albatross & Yellow-nosed albatross \\
\hline \multirow[t]{4}{*}{ Incubation } & Number of individuals tracked (M:F) & $10(8: 2)$ & $11(6: 5)$ & $11(5: 6)$ \\
\hline & Maximum distance from colony (km) & $1,850 \pm 788^{a, *}$ & $1,437 \pm 660^{a,{ }^{*}}$ & $852 \pm 394^{b}$ \\
\hline & Trip duration (days) & $9.90 \pm 4.04^{*}$ & $8.58 \pm 2.33^{*}$ & $7.31 \pm 3.04^{\star}$ \\
\hline & Mean transit rate $\left(\mathrm{km} \mathrm{h}^{-1}\right)$ & $29.3 \pm 4.87^{\mathrm{a}}$ & $27.2 \pm 5.85^{\mathrm{a},{ }^{\star}}$ & $19.0 \pm 4.00^{b}$ \\
\hline \multirow[t]{4}{*}{ Brooding } & Number of individuals tracked (M:F) & $15(7: 8)$ & $13(7: 6)$ & $15(7: 8)$ \\
\hline & Maximum distance from colony (km) & $420 \pm 213^{*}$ & $352 \pm 146^{\star}$ & $404 \pm 222$ \\
\hline & Trip duration (days) & $2.60 \pm 0.56^{*}$ & $2.78 \pm 0.82^{\star}$ & $3.97 \pm 1.64^{*}$ \\
\hline & Mean transit rate $\left(\mathrm{km} \mathrm{h}^{-1}\right)$ & $23.4 \pm 6.32^{\mathrm{a}}$ & $19.9 \pm 4.11^{\mathrm{ab},{ }^{*}}$ & $15.7 \pm 7.56^{b}$ \\
\hline
\end{tabular}

Different lowercase letters indicate significant differences $(P<0.05)$ among species; asterisks indicate significant differences between reproductive stages.
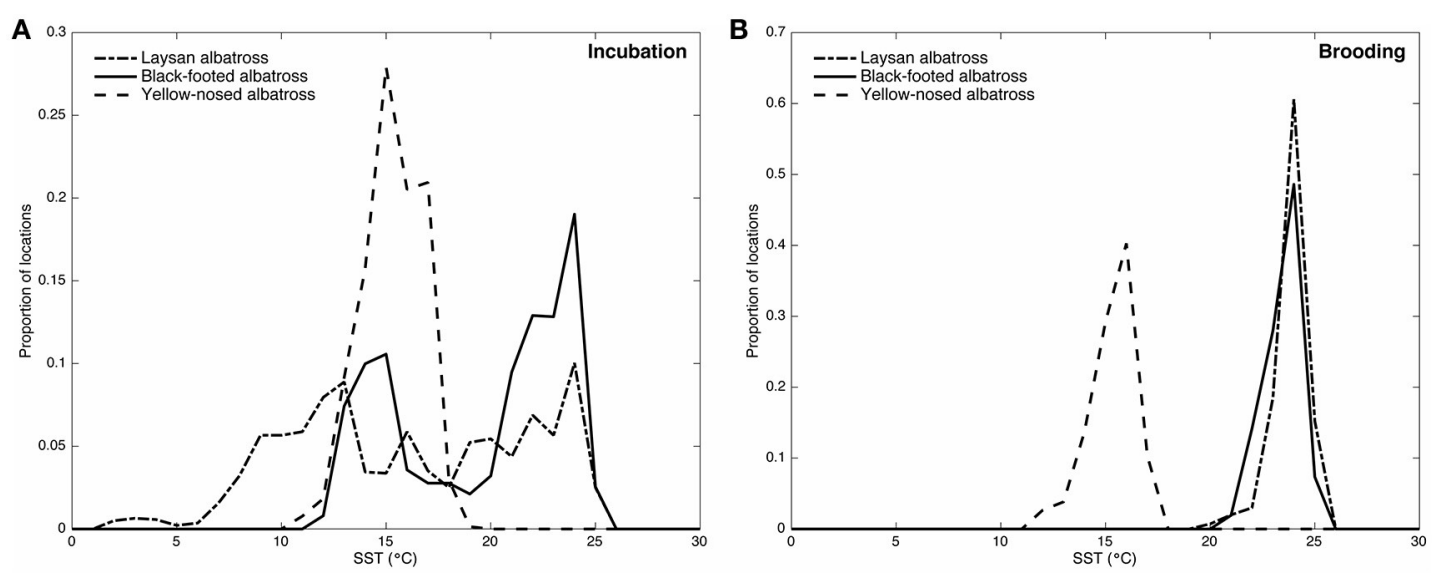

FIGURE 2 | Distribution of sea surface temperatures $\left({ }^{\circ} \mathrm{C}\right)$ along Laysan, black-footed, and Indian yellow-nosed albatrosses foraging routes during incubation (A) and brooding (B). Laysan and black-footed albatrosses were tracked at Tern Island, Northwest Hawaiian Islands during 2002-2003, 2004-2005, and 2005-2006, and yellow-nosed albatrosses were tracked at Amsterdam Island, southern Indian Ocean, during 2006-2007. Blended 5-day sea surface temperature retrieved via the NOAA OceanWatch Live Access Server (http://coastwatch.pfel.noaa.gov/erddap/).

during brooding $\left(8 \mathrm{~km} \mathrm{~h}^{-1}\right.$ on average; $\left.P=0.004\right)$, but this was the only species difference in transit rate observed. Sea surface temperature along foraging tracks was most similar among species during incubation; Hawaiian albatrosses used warmer waters than yellow-nosed albatrosses during brooding (Figure 2).

Percent time in flight and landing rates did not differ between reproductive stages for any of the three species (Table 2). During incubation, Hawaiian albatrosses spent more time in flight at night (70-80\%) compared to yellow-nosed albatrosses ( $~ 50 \%$; Table 2; $P<0.01$ for pair-wise tests). During brooding, Hawaiian albatrosses spent more time in flight both during the day ( $90 \%)$ and at night (80-90\%) compared to yellow-nosed albatrosses ( $\sim 70 \%$ during day; $\sim 40 \%$ at night; Table $2 ; P<$ 0.01 for pair-wise tests). Yellow-nosed albatrosses had higher overall and daytime landing rates than black-footed albatrosses during incubation $(P<0.001)$, but there were no species differences in overall or daytime landing rates during brooding. All three species demonstrated diel patterns in foraging activity (Table 2).

\section{Field Metabolic Rates}

Body mass differed between the three species studied; blackfooted albatrosses were significantly heavier than Laysan albatrosses $(P<0.001)$, which were significantly heavier than yellow-nosed albatrosses $(P=0.002$; Table 3$)$. Total body water (\%) did not differ significantly between Laysan and blackfooted albatrosses, but each species of Hawaiian albatross had a lower percentage of total body water compared to yellow-nosed albatrosses ( $P<0.001$ for pair-wise tests). On average, albatrosses gained mass during the foraging trip but the change in mass did not differ between species and was highly variable among individuals (Table 3).

Mean absolute $F M R_{a t-s e a}(\mathrm{~W})$ was greatest for black-footed albatrosses $(P=0.005$, Laysan pair-wise test; $P<0.001$, yellownosed pair-wise test), and similar for Laysan and yellow-nosed albatrosses (Table 3). Mean absolute $F M R_{\text {on-nest }}(\mathrm{W})$ did not differ between albatross species but sample sizes were low for this parameter (Table 3). Mass-specific $F M R_{a t-s e a}\left(\mathrm{~W} \mathrm{~kg}^{-1}\right)$ and $F M R_{\text {on-nest }}\left(\mathrm{W} \mathrm{kg}^{-1}\right)$ did not differ between species. The ratio of $F M R_{a t-s e a}$ to $F M R_{\text {on-nest }}$ was lowest for black-footed 
TABLE 2 | Summary characteristics (Mean $\pm S D$ ) of at-sea activity patterns of Laysan and black-footed albatrosses breeding at Tern Island, Northwest Hawaiian Islands, and Indian yellow-nosed albatrosses breeding at Amsterdam Island, southern Indian Ocean, during late incubation and brooding.

\begin{tabular}{|c|c|c|c|c|}
\hline Breeding period & & Laysan albatross & Black-footed albatross & Yellow-nosed albatross \\
\hline \multirow[t]{6}{*}{ Incubation } & Time in flight (\%) & $79.2 \pm 12.1^{\mathrm{ab}}$ & $83.5 \pm 7.69^{a}$ & $67.7 \pm 11.3^{b}$ \\
\hline & Day time in flight (\%) & $88.1 \pm 4.23^{\mathrm{a}}$ & $84.0 \pm 9.26^{\mathrm{ab}}$ & $78.8 \pm 9.02^{b}$ \\
\hline & Night time in flight (\%) & $71.3 \pm 20.1^{\mathrm{a}}$ & $83.0 \pm 9.15^{\mathrm{a}}$ & $46.7 \pm 17.1^{\mathrm{b}}$ \\
\hline & Landings per hour & $0.67 \pm 0.16^{a b}$ & $0.46 \pm 0.13^{a}$ & $0.86 \pm 0.16^{b}$ \\
\hline & Day landings per hour & $0.84 \pm 0.25^{a b}$ & $0.59 \pm 0.12^{a}$ & $1.21 \pm 0.25^{b}$ \\
\hline & Night landings per hour & $0.52 \pm 0.15^{a}$ & $0.35 \pm 0.19^{a b}$ & $0.21 \pm 0.11^{b}$ \\
\hline \multirow[t]{6}{*}{ Brooding } & Time in flight (\%) & $89.0 \pm 5.77^{a}$ & $84.1 \pm 8.72^{a}$ & $60.7 \pm 11.5^{\mathrm{b}}$ \\
\hline & Day time in flight (\%) & $91.4 \pm 3.11^{a}$ & $90.1 \pm 4.04^{a}$ & $69.8 \pm 12.8^{b}$ \\
\hline & Night time in flight (\%) & $87.0 \pm 10.7^{a}$ & $78.2 \pm 14.9^{a}$ & $43.5 \pm 18.6^{b}$ \\
\hline & Landings per hour & $0.85 \pm 0.28$ & $0.60 \pm 0.21$ & $0.84 \pm 0.41$ \\
\hline & Day landings per hour & $1.07 \pm 0.38$ & $0.83 \pm 0.37$ & $1.07 \pm 0.48$ \\
\hline & Night landings per hour & $0.65 \pm 0.24^{a}$ & $0.37 \pm 0.18^{b}$ & $0.39 \pm 0.36^{b}$ \\
\hline
\end{tabular}

Different lowercase letters indicate significant differences $(P<0.05)$ among species; there were no significant differences between reproductive stages.

TABLE 3 | Energy expenditure (Mean \pm SD) of Laysan and black-footed albatrosses breeding at Tern Island, Northwest Hawaiian Islands, and Indian yellow-nosed albatrosses breeding at Amsterdam Island, southern Indian Ocean, during the brooding period.

\begin{tabular}{|c|c|c|c|}
\hline & Laysan albatross & Black-footed albatross & Yellow-nosed albatross \\
\hline CO2 production at-sea $\left(\mathrm{mL} \mathrm{g}^{-1} \mathrm{~h}^{-1}\right)$ & $0.96 \pm 0.15(14)$ & $0.92 \pm 0.15(14)$ & $1.03 \pm 0.12(15)$ \\
\hline Absolute $F M R_{\text {at-sea }}(\mathrm{W})$ & $16.9 \pm 3.04^{\mathrm{a}}$ & $20.6 \pm 2.95^{b}$ & $16.2 \pm 2.68^{\mathrm{a}}$ \\
\hline Mass-specific $F M R_{a t-s e a}\left(\mathrm{~W} \mathrm{~kg}^{-1}\right)$ & $6.38 \pm 0.70$ & $6.43 \pm 0.91$ & $7.04 \pm 0.85$ \\
\hline Mean body mass (kg) & $2.69 \pm 0.34^{a}$ & $3.22 \pm 0.31^{b}$ & $2.30 \pm 0.20^{c}$ \\
\hline Total mass change (g) & $210 \pm 223$ & $80.0 \pm 202$ & $68.3 \pm 156$ \\
\hline Percent daily mass change (\%) & $2.88 \pm 3.13$ & $1.04 \pm 2.27$ & $0.77 \pm 1.72$ \\
\hline Total body water (\% initial body mass) & $46.8 \pm 2.44^{\mathrm{a}}$ & $45.9 \pm 4.09^{a}$ & $53.7 \pm 4.63^{b}$ \\
\hline Water influx rate $\left(\mathrm{mL} \mathrm{d}^{-1}\right)$ & $433 \pm 176$ & $458 \pm 97.2$ & $380 \pm 138$ \\
\hline CO2 production ${ }_{\mathrm{on}-\text { nest }}\left(\mathrm{mL} \mathrm{g}^{-1} \mathrm{~h}^{-1}\right)$ & $0.35 \pm 0.12(4)$ & $0.50 \pm 0.07(4)$ & $0.42 \pm 0.13(3)$ \\
\hline Absolute $F M R_{\text {on-nest }}(\mathrm{W})$ & $6.71 \pm 1.91$ & $10.1 \pm 1.73$ & $6.75 \pm 2.19$ \\
\hline Mass-specific $F M R_{\text {on-nest }}\left(\mathrm{W} \mathrm{kg}^{-1}\right)$ & $2.43 \pm 0.81$ & $3.44 \pm 0.45$ & $2.90 \pm 0.89$ \\
\hline
\end{tabular}

Sample sizes are given in parentheses. Different lowercase letters indicate significant differences $(P<0.05)$ among species.

albatrosses (1.9), and similar for Laysan (2.6) and yellow-nosed albatrosses (2.4).

For each species, we investigated the relationship between atsea behavior and mass-specific field metabolic rates, however, $F M R_{a t-s e a}\left(\mathrm{~W} \mathrm{~kg}^{-1}\right.$ ) was not statistically related to foraging range, trip duration, transit rates, the percent time in flight, the number or frequency of landings, change in mass, or water influx rates.

We plotted the allometric relationship between FMR and body mass for albatrosses from this and other doubly labeled water studies to provide a mechanism for appropriately comparing energy expenditure among species (Figure 3; Shaffer, 2011). We found a significant effect of the genus Diomedea on the relationship between log-transformed FMR and body mass $[\beta=$ $\left.0.60, t_{(6)}=3.19, P=0.02\right]$, therefore our discussion focuses on the allometric relationship of the smaller albatross species (solid line; Figure 3) rather than the line for all studied species (dashed line; Figure 3). We found that Hawaiian albatrosses during brooding fall below the regression line for smaller albatross species, whereas yellow-nosed albatrosses fall above this line (Figure 3).

\section{DISCUSSION}

\section{Comparative Foraging Behavior}

During the incubation period, all three albatross species foraged within convergence zones between warm subtropical waters and cool subpolar waters (Figure 1) where productivity is regionally enhanced (Lutjeharms and Valentine, 1984; Barange et al., 1998; Read et al., 2000; Olson, 2001; Polovina et al., 2001) and albatross prey resources are aggregated (Harrison et al., 1983; Gong et al., 1993; Yatsu et al., 1993; Pearcy et al., 1996; Pinaud et al., 2005; Conners, 2015). To reach these habitats, Laysan and black-footed albatrosses traveled significantly farther than yellow-nosed albatrosses and spent more time at sea. During brooding, all species reduced time at sea and Hawaiian albatrosses retracted their foraging ranges to the warm, oligotrophic environment close to the breeding colony 


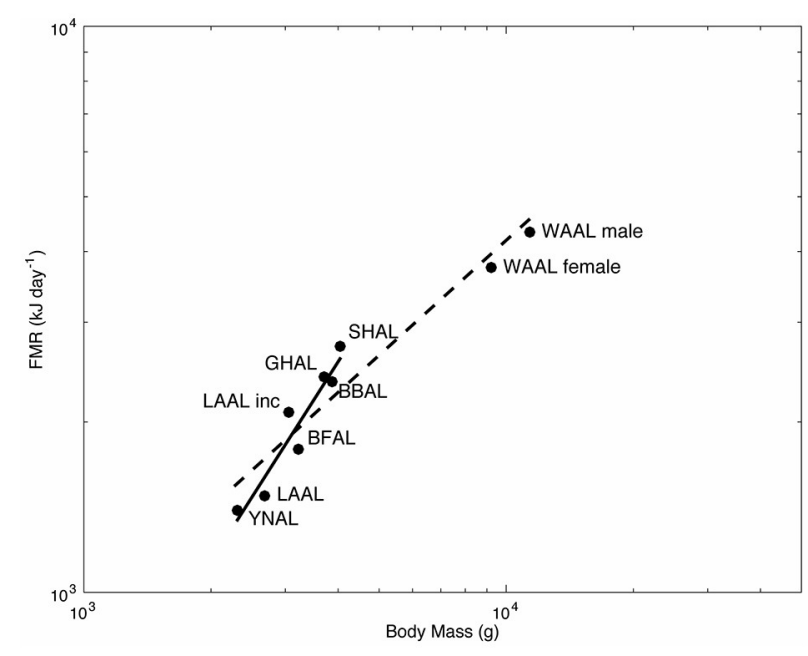

FIGURE 3 | Allometry of field metabolic rate (FMR; $\mathrm{kJ} \mathrm{d}^{-1}$ ) for albatrosses measured using the doubly labeled water method. FMR and body mass (g) are plotted on a logarithmic scale for WAAL male and female (wandering albatross Diomedea exulans; Shaffer et al., 2001a), SHAL (shy albatross Thalassarche cauta; Green and Brothers 1995, Abstract from First International Albatross and Petrel Conference, Hobart, Australia), GHAL (gray-headed albatross T. chrysostoma; Costa and Prince, 1987), BBAL (black-browed albatross T. melanophrys; Shaffer et al., 2004), LAAL Inc. (Laysan albatross Phoebastria immutabilis during incubation; Pettit et al., 1988), and BFAL (black-footed albatross P. nigripes), LAAL (Laysan albatross), and YNAL (Indian yellow-nosed albatross T. carteri) during brooding (this study).

(Figures 1, 2), where prey abundance is likely lower (Ashmole, 1971; Ballance et al., 1997). Conversely, yellow-nosed albatrosses were able to forage in a similar thermal environment during both reproductive stages, despite restricted movements during brooding (Figures 1, 2).

Hawaiian albatrosses spent more time in flight than yellownosed albatrosses, especially at night and during the brooding period. This is in agreement with our hypothesis, as we expected that spending more time in flight would be suitable for foraging in a low-productivity environment with unpredictable prey resources (Weimerskirch et al., 2005). Reliance on flight to travel between dispersed prey patches is seen in other tropical seabirds where greater flight proficiency is associated with lower productivity habitats (Ballance et al., 1997). Compared to other albatross species that forage in more productive marine habitats such as subtropical and polar convergences, continental shelfbreaks and slopes, and coastal upwelling zones (Tickell, 2000; BirdLife International, 2004), yellow-nosed albatrosses spent a similar proportion of time in flight (44-69\%; Weimerskirch and Guionnet, 2002; Phalan et al., 2007). Contrary to our hypothesis, we did not detect a consistent difference in overall landing rates between Hawaiian albatrosses and yellow-nosed albatrosses during brooding, despite contrasting foraging environments. Landing rates during brooding were similar between species during the day, but higher for Laysan albatrosses at night. Higher landing rates at night for Laysan albatrosses may be related to nocturnal feeding in this species (Harrison et al., 1983; Conners et al., 2015). The tendency of all species to forage during daylight hours is supported by previous research (Fernández and Anderson, 2000; Weimerskirch and Guionnet, 2002; Kappes et al., 2015).

\section{Foraging Energetics}

Brooding Laysan and black-footed albatrosses did not differ in terms of body composition; however, both Hawaiian albatrosses demonstrated significantly lower total body water when compared to yellow-nosed albatrosses. Lower total body water suggests that Hawaiian albatrosses have comparatively greater lipid reserves (Reilly and Fedak, 1990; Ellis and Jehl, 1991; Groscolas et al., 1991), which may be related to foraging in a lowproductivity environment. If foraging conditions are poor during brooding, adults may rely on lipid body stores obtained during the incubation period for self-maintenance and then allocate food resources acquired at sea during the brooding period to rapidly-growing chicks (Weimerskirch and Lys, 2000).

Mean absolute $F M R_{a t-s e a}$ was greatest for black-footed albatrosses, and similar for Laysan and yellow-nosed albatrosses. Greater absolute $F M R_{a t-s e a}$ in black-footed albatrosses can be explained by larger body size (Nagy, 2005) and higher wing loading in this species (Suryan et al., 2008). Contrary to our prediction, Laysan and black-footed albatrosses did not exhibit lower mass-specific $F M R_{\text {at-sea }}$ compared to yellownosed albatrosses. We expected that Hawaiian albatrosses would minimize foraging costs by employing a comparatively economical foraging strategy in response to sparse, unpredictable local prey resources (Flint and Nagy, 1984; Weimerskirch et al., 2005). We therefore also combined our results with published research and examined residual variation in the allometric relationship between body mass and $F M R_{a t-s e a}$ to further evaluate the comparative energy expenditure of Hawaiian and yellow-nosed albatrosses (discussed below).

We did not find significant relationships between $F M R_{a t-s e a}$ and foraging range, trip duration, transit rates, the percent time in flight, the number or frequency of landings, change in mass, or water influx rates within each species. As predicted, Hawaiian albatrosses spent more time in flight than yellow-nosed albatrosses, however, we were not able to detect a relationship between time in flight and energetic costs within species. During brooding, overall landing rates did not differ between species and were highly variable. Previous research using the doubly labeled water method demonstrated a relationship between energetic costs and landing rates in wandering albatrosses (Shaffer et al., 2001a), therefore we expected that landing rates would be related to energy expenditure within species in this study. The lack of a relationship between landing rates and field metabolic rates may be explained by the relatively smaller size of Hawaiian and yellow-nosed albatrosses $(2-4 \mathrm{~kg})$ compared to the larger wandering albatross (8-10 kg; Tickell, 1968).

While field metabolic rates of black-footed and yellownosed albatrosses have not been studied during incubation, Pettit et al. (1988) measured FMR at-sea and FMR on-nest of Laysan albatrosses at Tern Island during the incubation period. Estimates of $F M R_{\text {on-nest }}$ during incubation were similar to our estimates of FMR $R_{\text {on-nest }}$ during brooding, however, estimates of $F M R_{a t-s e a}$ during incubation were higher than our estimates of 
$F M R_{\text {at-sea }}$ during brooding for all three species (Pettit et al., 1988; Figure 3). This contrasts with a study of wandering albatrosses, where $F M R_{a t-s e a}$ was higher during brooding, compared to the incubation period (Shaffer et al., 2003). Although estimated $F M R_{a t-s e a}$ was greater during incubation for Laysan albatrosses, activity patterns during incubation and brooding were similar (this study; Kappes et al., 2015). This provides further evidence that activity patterns do not relate directly to energy expenditure in this species, contrary to findings for wandering albatrosses (Weimerskirch et al., 2000; Shaffer et al., 2001a). Higher $F M R_{a t-s e a}$ during the incubation period could reflect effort directed at assimilating lipid stores while foraging at distant, preferred habitats (Welcker et al., 2009), so that adults are able to effectively provision young chicks while foraging in an oligotrophic marine habitat during brooding.

To further examine variation in energy expenditure among species, we evaluated the allometric relationship between FMR and body mass for smaller albatross species and examined where Hawaiian and yellow-nosed albatrosses fell in relation to the plotted regression line (Figure 3). We found that Hawaiian albatrosses during brooding fell below the regression line, whereas yellow-nosed albatrosses fell above this line (Figure 3). This indicates that Hawaiian albatrosses expend comparatively less energy at sea during brooding after accounting for species differences in mass, which may be related to foraging in an oligotrophic environment during this reproductive stage. It may also be related to the fact that Hawaiian albatrosses breed during boreal winter when winds are stronger, compared to conditions during the Indian Ocean austral summer when yellow-nosed albatrosses breed. Laysan albatrosses during incubation fall well above the regression line, indicating that this species expends comparatively more energy during this reproductive stage, which may be related to effort directed at assimilating lipid stores in distant, preferred habitats.

\section{CONCLUSIONS}

Among albatrosses, Hawaiian albatrosses are unique in that they are constrained to forage in a warm, oligotrophic marine environment during the energetically demanding brooding period. As hypothesized, Hawaiian albatrosses spent more time in flight than yellow-nosed albatrosses during brooding, a behavior suited for traveling between dispersed prey patches. Contrary to our predictions, we did not detect species differences in overall landing rates or mass-specific $F M R_{a t-s e a}$ during brooding, measures indicative of foraging energy expenditure. However, compared to yellow-nosed albatrosses, Hawaiian albatrosses had lower total body water (greater lipid reserves) and field metabolic rates that fell below the allometric relationship for studied albatross species, attributes which may reflect physiological adaptations of these species to foraging in a low-productivity environment. Given the relative lack of information on the physiological constraints of species movements (Hays et al., 2016), our comparative approach provides a valuable case study as to how a group of related species responds physiologically and behaviorally to differing environmental conditions and reproductive demands.

\section{DATA AVAILABILITY}

Satellite tracking datasets generated from this research are available by request from the BirdLife Tracking Ocean Wanderers database (http://seabirdtracking.org).

\section{AUTHOR CONTRIBUTIONS}

All authors participated in study design and interpretation of results. MA and YT: collected tracking data; MA, DC, and SS: implemented the doubly labeled water technique in the field; MA: performed laboratory work, conducted data analysis, and implemented statistical analyses; MA: wrote the first draft of the manuscript, and all authors contributed substantially to revisions.

\section{FUNDING}

This research was part of the Tagging of Pacific Pelagics (TOPP) program, funded in part by the National Ocean Partnership Program (N00014-02-1-1012), the Office of Naval Research (N00014-00-1-0880 \& N00014-03-1-0651), the Gordon and Betty Moore, David and Lucille Packard, and Alfred P. Sloan Foundations. MA was supported by a Fulbright grant to France, a Chancellor's Dissertation-Year Fellowship and a UCSC Regents Fellowship, and grants from the ARCS Foundation, the Earl H. Myers and Ethel M. Myers Trust, Friends of Long Marine Lab, the Society for Integrative and Comparative Biology, the STEPS Institute, and the UCSC Ecology \& Evolutionary Biology department. Cambridge Isotope Laboratories, Inc. provided deuterium and oxygen-18 isotopes for this study as a research award. S \& A Machine and Tool Co. generously provided overseas shipping costs of research supplies for use on Amsterdam Island.

\section{ACKNOWLEDGMENTS}

We thank Jill Awkerman, Sarah Chisholm, Peter Kappes, Nicolas Mignot, Scott Seganti, and Jean-Baptiste Thiebot for invaluable assistance in the field, and Lindsay Young for conducting genetic sexing. We are grateful to the Hawaiian Islands National Wildlife Refuge, U.S. Fish and Wildlife Service, Department of the Interior, for logistic support and permission to conduct research on Tern Island; to L'Institut Polaire Français and Terres Australes et Antarctiques Françaises for supporting field activities on Amsterdam Island; and to the Fulbright Commission for supporting research on Amsterdam Island, and while in residence at Centre d'Études Biologiques de Chizé (CNRS). 


\section{REFERENCES}

Alerstam, T., and Högstedt, G. (1982). Bird migration and reproduction in relation to habitats for survival and breeding. Ornis Scand. 13, 25-37. doi: $10.2307 / 3675970$

Ashmole, N. P. (1971). "Seabird ecology and the marine environment," in Avian Biology, eds D. S. Farner and J. R. King (London: Academic Press), 223-286.

Backus, R. H. (1986). "Biogeographic boundaries in the open ocean," in Pelagic Biogeography, Vol. 49, eds A. C. Pierrot-Bults, S. van der Spoel, B. J. Zahuranec, and R. K. Johnson (UNESCO Technical Paper in Marine Science), 9-13.

Ballance, L. T., Pitman, R. L., and Reilly, S. B. (1997). Seabird community structure along a productivity gradient: importance of competition and energetic constraint. Ecology 78, 1502-1518. doi: 10.1890/00129658(1997)078[1502:SCSAAP]2.0.CO;2

Barange, M., Pakhomov, E. A., Perissinotto, R., Froneman, P. W., Verheye, H. M., Taunton-Clark, J., et al. (1998). Pelagic community structure of the subtropical convergence region south of Africa and in the mid-Atlantic Ocean. Deep Sea Res. I 45, 1663-1687. doi: 10.1016/S0967-0637(98)00037-5

BirdLife International (2004). "Tracking ocean wanderers: the global distribution of albatrosses and petrels," in Results from the Global Procellariiform Tracking Workshop, (1-5 September, 2003) (Gordon's Bay; Cambridge, UK: BirdLife International).

Charnov, E. L. (1976). Optimal foraging, the marginal value theorem. Theor. Popul. Biol. 9, 129-136. doi: 10.1016/0040-5809(76)90040-X

Conners, M. G. (2015). Comparative Behavior, Diet, and Post-Breeding Strategies of Two Sympatric North Pacific albatross Species (Phoebastria sp.). Ph.D. dissertation, University of California, Santa Cruz.

Conners, M. G., Hazen, E. L., Costa, D. P., and Shaffer, S. A. (2015). Shadowed by scale: subtle behavioral niche partitioning in two sympatric, tropical breeding albatross species. Mov. Ecol. 3, 28. doi: 10.1186/s40462-015-0060-7

Costa, D. P. (1991). Reproductive and foraging energetics of high latitude penguins, albatrosses and pinnipeds: implications for life history patterns. Am. Zool. 31, 111-130. doi: 10.1093/icb/31.1.111

Costa, D. P. (1993). The relationship between reproductive and foraging energetics and the evolution of the Pinnipedia. Symp. Zool. Soc. Lond. 66, 293-314.

Costa, D. P., and Prince, P. A. (1987). Foraging energetics of gray-headed albatrosses Diomedea Chrysostoma at Bird Island, South Georgia. Ibis 129, 149-158. doi: 10.1111/j.1474-919X.1987.tb03196.x

Costa, D. P., and Shaffer, S. A. (2008). "Physiological constraints on the foraging ecology and energetics of albatrosses and other large seabirds," in 4th $C P B$ Meeting in Africa: Mara 2008. Molecules to Migration: The Pressures of Life, eds S. Morris and A. Vosloo (Bologna: Medimond Publishing).

Costa, D. P., and Shaffer, S. A. (2012). "Seabirds and marine mammals," in Metabolic Ecology: A Scaling Approach, eds R. M. Sibly, J. H. Brown, and A. Kodric-Brown (Oxford: John Wiley \& Sons, Ltd.), 225-233.

Croll, D. A., Marinovic, B., Benson, S., Chavez, F. P., Black, N., Ternullo, R., et al. (2005). From wind to whales: trophic links in a coastal upwelling system. Mar. Ecol. Prog. Ser. 289, 117-130. doi: 10.3354/meps 289117

Ellis, H. I., and Jehl, J. R. (1991). Total body water and body composition in phalaropes and other birds. Physiol. Zool. 64, 973-984. doi: 10.1086/physzool.64.4.30157952

Emlen, J. M. (1966). The role of time and energy in food preference. Am. Nat. 100, 611-617. doi: 10.1086/282455

Fauchald, P., Erikstad, K. E., and Skarsfjord, H. (2000). Scale-dependent predator-prey interactions: the hierarchical spatial distribution of seabirds and prey. Ecology 81, 773-783. doi: 10.3354/meps 231279

Fernández, P., and Anderson, D. J. (2000). Nocturnal and diurnal foraging activity of Hawaiian albatrosses detected with a new immersion monitor. Condor 102, 577-584. doi: 10.1650/0010-5422(2000)102[0577:NADFAO]2.0.CO;2

Fernández, P., Anderson, D. J., Sievert, P. R., and Huyvaert, K. P. (2001). Foraging destinations of three low-latitude albatross (Phoebastria) species. J. Zool. 254, 391-404. doi: 10.1017/S0952836901000899

Flint, E. N., and Nagy, K. A. (1984). Flight energetics of free-living sooty terns. Auk $101,288-294$.

Franks, P. J. S. (1992). Sink or swim: accumulation of biomass at fronts. Mar. Ecol. Prog. Ser. 82, 1-12. doi: 10.3354/meps082001
Freitas, C., Lydersen, C., Fedak, M. A., and Kovacs, K. M. (2008). A simple new algorithm to filter marine mammal Argos locations. Mar. Mamm. Sci. 24, 315-325. doi: 10.1111/j.1748-7692.2007.00180.x

Fridolfsson, A.-K., and Ellegren, H. (1999). A simple and universal method for molecular sexing of non-ratite birds. J. Avian Biol. 30, 116-121. doi: $10.2307 / 3677252$

Gong, Y., Kim, S., and An, D. H. (1993). Abundance of neon flying squid in relation to oceanographic conditions in the North Pacific. Int. N. Pac. Fish. Comm. Bull. $53,191-204$.

Govoni, J. J., and Grimes, C. B. (1992). The surface accumulation of larval fishes by hydrodynamic convergence within the Mississippi River plume front. Cont. Shelf Res. 12, 1265-1276. doi: 10.1016/0278-4343(92)90063-P

Groscolas, R., Schreiber, L., and Morin, F. (1991). The use of tritiated water to determine protein and lipid utilization in fasting birds: a validation study in incubating great-winged petrels, Pterodroma macroptera. Physiol. Zool. 64, 1217-1233. doi: 10.1086/physzool.64.5.30156241

Guinet, C., Koudil, M., Bost, C.-A., Durbec, J. P., Georges, J. Y., Mouchot, M. C., et al. (1997). Foraging behaviour of satellite-tracked king penguins in relation to sea-surface temperatures obtained by satellite telemetry at Crozet Archipelago, a study during three austral summers. Mar. Ecol. Prog. Ser. 150, 11-20. doi: 10.3354/meps150011

Harding, A., Paredes, R., Suryan, R., Roby, D., Irons, D., Orben, R., et al. (2013). Does location really matter? An inter-colony comparison of seabirds breeding at varying distances from productive oceanographic features in the Bering Sea. Deep-Sea Res. II 94, 178-191. doi: 10.1016/j.dsr2.2013.03.013

Harrison, C. S., Hida, T. S., and Seki, M. P. (1983). Hawaiian seabird feeding ecology. Wildlife Wildl. Monogr. 85, 1-71.

Hays, G. C., Åkesson, S., Godley, B. J., Luschi, P., and Santidrian, P. (2001). The implications of location accuracy for the interpretation of satellite-tracking data. Anim. Behav. 61, 1035-1040. doi: 10.1006/anbe.2001.1685

Hays, G. C., Ferreira, L. C., Sequeira, A. M. M., Meekan, M. G., Duarte, C. M., Bailey, H., et al. (2016). Key questions in marine megafauna movement ecology. Trends Ecol. Evol. 31, 463-475. doi: 10.1016/j.tree.2016.02.015

Hothorn, T., Bretz, F., and Westfall, P. (2008). Simultaneous inference in general parametric models. Biometr. J. 50, 346-363. doi: 10.1002/bimj.200810425

Houston, A. I. (1993). The efficiency of mass loss in breeding birds. Proc. R. Soc. Lond. B 254, 221-225. doi: 10.1098/rspb.1993.0149

Hunt, G. L. (1997). Physics, zooplankton, and the distribution of least auklets in the Bering Sea - a review. ICES J. Mar. Sci. 54, 600-607. doi: $10.1006 /$ jmsc.1997.0267

Hunt, G. L., Russell, R. W., Coyle, K. O., and Weingartner, T. (1998). Comparative foraging ecology of planktivorous auklets in relation to ocean physics and prey availability. Mar. Ecol. Prog. Ser. 167, 241-259. doi: 10.3354/meps167241

Hyrenbach, K. D., Fernandez, P., and Anderson, D. J. (2002). Oceanographic habitats of two sympatric North Pacific albatrosses during the breeding season. Mar. Ecol. Prog. Ser. 233, 283-301. doi: 10.3354/meps233283

Jouventin, P., and Weimerskirch, H. (1990). Satellite tracking of wandering albatrosses. Nature 343, 746-748. doi: 10.1038/343746a0

Kappes, M. A., Shaffer, S. A., Tremblay, Y., Foley, D. G., Palacios, D. M., Bograd, S. J., et al. (2015). Reproductive constraints influence habitat accessibility, segregation, and preference of sympatric albatross species. Mov. Ecol. 3:34. doi: 10.1186/s40462-015-0063-4

Kappes, M. A., Shaffer, S. A., Tremblay, Y., Foley, D. G., Palacios, D. M., Robinson, P. W., et al. (2010). Hawaiian albatrosses track interannual variability of marine habitats in the North Pacific. Prog. Oceanogr. 86, 246-260. doi: 10.1016/j.pocean.2010.04.012

Keating, K. A. (1994). An alternative index of satellite telemetry location error. J. Wildl. Manage. 58, 414-421. doi: 10.2307/3809311

Keiper, C. A., Ainley, D. G., Allen, S. G., and Harvey, J. T. (2005). Marine mammal occurrence and ocean climate off central California, 1986 to 1994 and 1997 to 1999. Mar. Ecol. Prog. Ser. 289, 285-306. doi: 10.3354/meps 289285

Levins, R. (1968). Evolution in Changing Environments: Some Theoretical Explorations. Princeton, NJ: Princeton University Press.

Lewin-Koh, N. J., and Bivand, R. (2010). Maptools: Tools for Reading and Handling Spatial Objects. R Package Version 0.7-34.

Lifson, N., and McClintock, R. (1966). Theory of use of the turnover rates of body water for measuring energy and material balance. J. Theor. Biol. 12, 46-74. doi: 10.1016/0022-5193(66)90185-8 
Lutjeharms, J. R. E., and Valentine, H. R. (1984). Southern Ocean thermal fronts south of Africa. Deep Sea Res. 31, 1461-1475. doi: 10.1016/0198-0149(84)90082-7

MacArthur, R. H., and Pianka, E. R. (1966). On optimal use of a patchy environment. Am. Nat. 100, 603-609. doi: 10.1086/282454

MacKas, D. L., and Boyd, C. M. (1979). Spectral analysis of zooplankton spatial heterogeneity. Science 204, 62-64. doi: 10.1126/science.204.4388.62

Nagy, K. A. (1980). $\mathrm{CO}_{2}$ production in animals: analysis of potential errors in the doubly labeled water method. Am. J. Physiol. 238, R466-R473.

Nagy, K. A. (2005). Field metabolic rate and body size. J. Exp. Biol. 208, 1621-1625. doi: $10.1242 /$ jeb. 01553

Olson, D. B. (2001). Biophysical dynamics of western transition zones: a preliminary synthesis. Fish. Oceanogr. 10, 133-150. doi: 10.1046/j.1365-2419.2001.00161.x

Olson, D. B., and Backus, R. H. (1985). The concentrating of organisms at fronts: a cold-water fish and a warm-core ring. J. Mar. Res. 43, 113-137. doi: $10.1357 / 002224085788437325$

Olson, D. B., Hitchcock, G. L., Mariano, A. J., Ashjian, C. J., Peng, G., Nero, R. W., et al. (1994). Life on the edge: marine life and fronts. Oceanography 7, 52-59. doi: 10.5670/oceanog.1994.03

Olsson, O., and Bolin, A. (2014). A model for habitat selection and species distribution derived from central place foraging theory. Oecologia 175, 537-548. doi: 10.1007/s00442-014-2931-9

Orians, G. H., and Pearson, N. E. (1979). "On the theory of central place foraging," in Analysis of Ecological Systems, eds D. J. Horn, G. R. Stairs, and R. D. Mitchell (Columbus, OH: Ohio State University Press), 155-177.

Ortiz, C. L., Costa, D. P., and Le Boeuf, B. J. (1978). Water and energy flux in elephant seal pups fasting under natural conditions. Physiol. Zool. 51, 166-178. doi: 10.1086/physzool.51.2.30157864

Pearcy, W. G., Fisher, J. P., Anma, G., and Meguro, T. (1996). Species associations of epipelagic nekton of the North Pacific Ocean, 1978-1993. Fish. Oceanogr. 5, 1-20. doi: 10.1111/j.1365-2419.1996.tb00013.x

Pennycuick, C. J. (1982). The flight of petrels and albatrosses (Procellariiformes), observed in South Georgia and its vicinity. Philos. Trans. R. Soc. Lond. B 300, 75-106. doi: 10.1098/rstb.1982.0158

Pennycuick, C. J., Croxall, J. P., and Prince, P. A. (1984). Scaling of foraging radius and growth rate in petrels and albatrosses (Procellariiformes). Ornis Scand. 15, 145-154. doi: $10.2307 / 3675955$

Pettit, T. N., Nagy, K. A., Ellis, H. I., and Whittow, G. C. (1988). Incubation energetics of the Laysan albatross. Oecologia 74, 546-550. doi: 10.1007/BF00380052

Phalan, B., Phillips, R. A., Silk, J. R. D., Afanasyev, V., Fukuda, A., Fox, J., et al. (2007). Foraging behaviour of four albatross species by night and day. Mar. Ecol. Prog. Ser. 340, 271-286. doi: 10.3354/meps 340271

Phillips, R. A., Xavier, J. C., and Croxall, J. P. (2003). Effects of satellite transmitters on albatrosses and petrels. Auk 120, 1082-1090. doi: 10.1642/00048038(2003)120[1082:EOSTOA]2.0.CO;2

Pinaud, D., Cherel, Y., and Weimerskirch, H. (2005). Effect of environmental variability on habitat selection, diet, provisioning behaviour and chick growth in yellow-nosed albatrosses. Mar. Ecol. Prog. Ser. 298, 295-304. doi: $10.3354 /$ meps 298295

Pinaud, D., and Weimerskirch, H. (2005). Scale-dependent habitat use in a long-ranging central place predator. J. Anim. Ecol. 74, 852-863. doi: 10.1111/j.1365-2656.2005.00984.x

Polovina, J. J., Howell, E., Kobayashi, D. R., and Seki, M. P. (2001). The transition zone chlorophyll front, a dynamic global feature defining migration and forage habitat for marine resources. Prog. Oceanogr. 49, 469-483. doi: 10.1016/S0079-6611(01)00036-2

Pyke, G. H. (1984). Optimal foraging theory: a critical review. Annu. Rev. Ecol. Syst. 15, 523-575. doi: 10.1146/annurev.es.15.110184.002515

R Development Core Team (2010). R: A Language and Environment for Statistical Computing. Vienna: R Foundation for Statistical Computing.

Read, J. F., Lucas, M. I., Holley, S. E., and Pollard, R. T. (2000). Phytoplankton, nutrients and hydrography in the frontal zone between the Southwest Indian Subtropical gyre and the Southern Ocean. Deep Sea Res. I 47, 2341-2368. doi: 10.1016/S0967-0637(00)00021-2
Reilly, J. J., and Fedak, M. A. (1990). Measurement of the body composition of living gray seals by hydrogen isotope dilution. J. Appl. Physiol. 69, 885-891.

Ricklefs, R. E. (1983). Some considerations on the reproductive energetics of pelagic seabirds. Stud. Avian Biol. 8, 84-94.

Russell, R. W., Hunt, G. L., Coyle, K. O., and Cooney, R. T. (1992). Foraging in a fractal environment: spatial patterns in a marine predator-prey system. Landsc. Ecol. 7, 195-209. doi: 10.1007/BF00133310

Schneider, D. C. (1990). Seabirds and fronts: a brief overview. Polar Res. 8, 17-21. doi: $10.3402 /$ polar.v8i1.6798

Shaffer, S. A. (2011). A review of seabird energetics using the doubly labeled water method. Comp. Biochem. Physiol. A 158, 315-322. doi: 10.1016/j.cbpa.2010.07.012

Shaffer, S. A., Costa, D. P., and Weimerskirch, H. (2001a). Behavioural factors affecting foraging effort of breeding wandering albatrosses. J. Anim. Ecol. 70, 864-874. doi: 10.1046/j.0021-8790.2001.00548.x

Shaffer, S. A., Costa, D. P., and Weimerskirch, H. (2001b). Comparison of methods for evaluating energy expenditure of incubating wandering albatrosses. Physiol. Biochem. Zool. 74, 823-831. doi: 10.1086/323650

Shaffer, S. A., Costa, D. P., and Weimerskirch, H. (2003). Foraging effort in relation to the constraints of reproduction in free-ranging albatrosses. Funct. Ecol. 17, 66-74. doi: 10.1046/j.1365-2435.2003.00705.x

Shaffer, S. A., Costa, D. P., and Weimerskirch, H. (2004). Field metabolic rates of black-browed albatrosses Thalassarche melanophrys during the incubation stage. J. Avian Biol. 35, 551-558. doi: 10.1111/j.0908-8857.2004.0 3264. $\mathrm{x}$

Shaffer, S. A., Gabrielsen, G. W., Verreault, J., and Costa, D. P. (2006). Validation of water flux and body composition in glaucous gulls (Larus hyperboreus). Physiol. Biochem. Zool. 79, 836-845. doi: 10.1086/504611

Sibly, R. M., Brown, J. H., and Kodric-Brown, A. (2012). Metabolic Ecology: A Scaling Approach. Oxford: John Wiley \& Sons, Ltd.

Speakman, J. R. (1997). Doubly Labelled Water: Theory and Practice. London: Chapman and Hall.

Spear, L. B., and Ainley, D. G. (1997). Flight speed of seabirds in relation to wind speed and direction. Ibis 139, 234-251. doi: 10.1111/j.1474-919X.1997.tb04621.x

Suryan, R. M., Anderson, D. J., Shaffer, S. A., Roby, D. D., Tremblay, Y., Costa, D. P., et al. (2008). Wind, waves, and wing loading: morphological specialization may limit range expansion of endangered albatrosses. PLoS ONE 3:e4016. doi: 10.1371 /journal.pone.0004016

Suryan, R. M., Sato, F., Balogh, G. R., Hyrenbach, K. D., Sievert, P. R., and Ozaki, K. (2006). Foraging destinations and marine habitat use of short-tailed albatrosses: a multi-scale approach using first-passage time analysis. Deep-Sea Res. II 53, 370-386. doi: 10.1016/j.dsr2.2006.01.012

Tickell, W. L. N. (1968). The biology of the great albatrosses, Diomedea exulans and Diomedea epomophora. Antarct. Res. Ser. 12, 1-55.

Tickell, W. L. N. (2000). Albatrosses. New Haven, CT: Yale University Press.

Weimerskirch, H. (2007). Are seabirds foraging for unpredictable resources? Deep-Sea Res. II 54, 211-223. doi: 10.1016/j.dsr2.2006.11.013

Weimerskirch, H., and Cherel, Y. (1998). Feeding ecology of short-tailed shearwaters: breeding in Tasmania and foraging in the Antarctic? Mar. Ecol. Prog. Ser. 167, 261-274. doi: 10.3354/meps167261

Weimerskirch, H., Cherel, Y., Cuenot-Chaillet, F., and Ridoux, V. (1997). Alternative foraging strategies and resource allocation by male and female wandering albatrosses. Ecology 78, 2051-2063. doi: 10.1890/00129658(1997)078[2051:AFSARA]2.0.CO;2

Weimerskirch, H., Gault, A., and Cherel, Y. (2005). Prey distribution and patchiness: factors in foraging success and efficiency of wandering albatrosses. Ecology 86, 2611-2622. doi: 10.1890/04-1866

Weimerskirch, H., and Guionnet, T. (2002). Comparative activity pattern during foraging of four albatross species. Ibis 144, 40-50. doi: 10.1046/j.0019-1019.2001.00021.x

Weimerskirch, H., Guionnet, T., Martin, J., Shaffer, S. A., and Costa, D. P. (2000). Fast and fuel efficient? Optimal use of wind by flying albatrosses. Proc. R. Soc. Lond. B 267, 1869-1874. doi: 10.1098/rspb.2000.1223

Weimerskirch, H., and Lys, P. (2000). Seasonal changes in the provisioning behaviour and mass of male and female wandering albatrosses in relation to the growth of their chick. Polar Biol. 23, 733-744. doi: 10.1007/s003000000144 
Weimerskirch, H., Salamolard, M., Sarrazin, F., and Jouventin, P. (1993). Foraging strategy of wandering albatrosses through the breeding season: a study using satellite telemetry. Auk 110, 325-342.

Welcker, J., Harding, A. M. A., Kitaysky, A. S., Speakman, J. R., and Gabrielsen, G. W. (2009). Daily energy expenditure increases in response to low nutritional stress in an Arctic-breeding seabird with no effect on mortality. Funct. Ecol. 23, 1081-1090. doi: 10.1111/j.1365-2435.2009. 01585.x

Wilson, R. P., Weimerskirch, H., and Lys, P. (1995). A device for measuring seabird activity at sea. J. Avian Biol. 26, 172-175. doi: 10.2307/3677067

Yatsu, A., Shimada, H., and Murata, M. (1993). Distributions of epipelagic fishes, squids, marine mammals, seabirds and sea turtles in the Central North Pacific. Int. N. Pac. Fish Comm. Bull. 53, 111-146.
Conflict of Interest Statement: The authors declare that the research was conducted in the absence of any commercial or financial relationships that could be construed as a potential conflict of interest.

The reviewer GS and handling Editor declared their shared affiliation.

Copyright $\odot 2017$ Antolos, Shaffer, Weimerskirch, Tremblay and Costa. This is an open-access article distributed under the terms of the Creative Commons Attribution License (CC BY). The use, distribution or reproduction in other forums is permitted, provided the original author(s) or licensor are credited and that the original publication in this journal is cited, in accordance with accepted academic practice. No use, distribution or reproduction is permitted which does not comply with these terms. 